\title{
Drivers to Enhance ICT Uptake in IBS Management Processes in the Construction Industry
}

\author{
Peniel Ang Soon Ern ${ }^{1, a}$, Narimah Kasim ${ }^{2}$ and Goh Kai Chen ${ }^{2}$ \\ ${ }^{1}$ Department of Civil Engineering Technology, Faculty of Engineering Technology, Universiti Tun Hussein Onn \\ Malaysia, 86400 Parit Raja, Johor, Malaysia \\ ${ }^{2}$ Department of Construction Management, Faculty of Technology Management and Business, Universiti Tun \\ Hussein Onn Malaysia, 86400 Parit Raja, Johor, Malaysia
}

\begin{abstract}
In Malaysia, as a result of the government's initiative and future outlook in advancing the use of innovative technologies, the Industrialised Building System (IBS) approach is actively promoted through several strategies and incentives as an alternative to conventional building methods. Extensive uptakes of modern Information Communication Technology (ICT) applications are able to support the different IBS processes for effective production. However, it is argued that ICT uptake at the organisational level is still in its infancy. This raises the importance to identify critical drivers for effective uptake of ICT in the IBS production management process. Critical drivers to ICT uptake were identified through questionnaire survey with industry stakeholders which was analysed using mean index and critical t-value with the use of SPSS software. The top ten priority ranked drivers reflect the People, Technology and Policy elements to ICT uptake. These identified critical drivers are able enhance ICT uptake in IBS management process in the construction industry.
\end{abstract}

\section{Introduction}

Industrialised Building System (IBS) is defined as a construction technique in which components are manufactured in a controlled environment (on or off site), transported, positioned and assembled into a structure with minimal additional site works [1]. The benefits of IBS, also called offsite construction have been widely studied and include reductions in time, defects, health and safety risks, environmental impact, and whole-life cost with a consequent increase in predictability, productivity, whole-life performance and profitability [2-6].

Appropriate implementation of Information Communication Technology (ICT) will facilitate more effective and productive materials management processes. Thus, widespread use of modern Information Technology (IT) tools will support the different IBS processes by enabling more accurate documents and good conditions for an effective production. Besides that, errors are discovered early and problems in the manufacturing and assembly phases can be avoided [7].

However, [8] indicated low IT adoption and limited technology availability to have generally discouraged IBS uptake in Malaysia. In point of fact, IT has been identified as one of the Critical Success Elements (CSF) or enablers for IBS adoption [9]. Hence, this paper aims to highlighting the critical drivers to enhance ICT uptake in the IBS management process.

\footnotetext{
${ }^{\mathrm{a}}$ Corresponding author : peniel@uthm.edu.my
} 


\section{Uptake in IBS Management Process}

More sophisticated solutions of ICT based technologies in IBS processes are emerging, such as wireless communication, bar-coding and Radio Frequency Identification (RFID) for tagging technologies. A report by Construction Research Institute of Malaysia [10] pointed technology as a main support to impact IBS in the future. 'Building Information Modeling (BIM)' and 'new technology for IBS invented' were classified as the highest ranking scenario of positive impacts on high-high analysis (high impact-high possibilities). In addition, it was stated that further improvement of manufacturing technology is a strong solution to tackle the weakness and threats of IBS adoption.

However, the current practice of ICT uptake in the tracking of IBS components in Malaysia is rather uncommon. There is a lack of effective logistics management in the Malaysian construction industry, where technology intervention plays a very critical role [11]. IBS production process needs a sustained improvement and management in order to ensure proper components are developed and handed over at the right time, in the proper order and without damages.

Recent findings on ICT uptake in IBS management process indicate that most of the problems or issues faced were normally solved with human solution or by technical menial methods [12]. ICT applications were not regarded as the best practices in overcoming the IBS components management problems. Few problems that cause the limited benefits of ICT uptake in the construction project level are lack of software integration (lack of a standardised platform for information exchange [15] and lack of standard processes for construction project management [16].

The shortcomings of ICT uptake in the construction industry bring forth a need to review possible driver elements for improving ICT uptake in the industry. Several research publications [17-21] indicate that people, process and technology are the three key elements that need to be considered for successful uptake of technologies. Together, these three elements create business value [21]. However, he further states that "the people, processes, and technology need a leader", just as "an orchestra needs a conductor". The same analogy can be applied to the adoption and uptake of new and innovative technologies within construction companies. The "conductor" in this case is the policy making. To successfully implement and use any new technology it requires policy makers to plan and drive policies and strategies. Policies are "written principles or rules to guide decision-making" [22]. All four elements are considered important for an organisation to effectively employ ICT. A company cannot employ ICT if it satisfies the requirements of just one element and not the others. Hence, all four elements - policy, process, people and technology - need to work hand-in-hand and symbiotically (refer Figure 1).

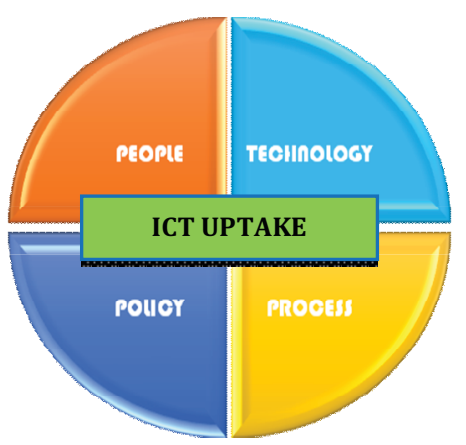

Figure 1. Driver elements for ICT uptake.

Taking this into account, the ICT uptake model has been so structured that for an organisation to employ ICT it must have: (a) Policy Makers that believes in the technology and takes strategic measures to drive its adoption, uptake and usage in order to mobilise the industry to implement and benefit from it, (b) Processes that enable and support the successful adoption of the technology, (c) 
People who have adequate skills, understanding of, and belief in, the technology; and finally (d) Technology applications and infrastructures which are adequate. The four elements to ICT uptake will form the theoretical basis to identify critical drivers for the enhancement of ICT uptake in IBS management process.

\section{Methodology}

This paper applies the method of purposive sampling, where the samples are selected based on the knowledge of a population and the purpose of the study [23]. This is a form of non-probability sampling in which it includes specialist knowledge of the research issue. Apart from the government IBS policy makers, IBS precast manufacturers are the selected respondents which form the biggest population among the other four IBS systems (e.g. IBS formwork, IBS steel systems) in Malaysia (refer Table 1).

Table 1. IBS manufacturers in Malaysia.

\begin{tabular}{|c|c|}
\hline Types of IBS Components & Total Manufacturer \\
\hline Pre-cast concrete framing, panel and box system & 30 \\
Steel framework system & 24 \\
Steel framing system & 25 \\
Prefabricated timber framing system & 4 \\
Block work system & 25 \\
Others (on-site) & 10 \\
\hline Grand total & 118 \\
\hline
\end{tabular}

Out of 41 questionnaires sent, a total of 31 was returned, giving a $76 \%$ high response rate from the construction industry, which in general stands at only $25 \%$ to $35 \%$ [24]. The questionnaire was sent to 33 organisastions from the listed companies, whom the majority are manufacturers under the Registered IBS System Provider (RISP) list in Malaysia. In addition, 8 questionnaires were distributed to the government policy makers who are direct decision makers to the issues pertaining to IBS. The data collection focused on the IBS precast manufacturing process, where ICT applications are more significantly used.

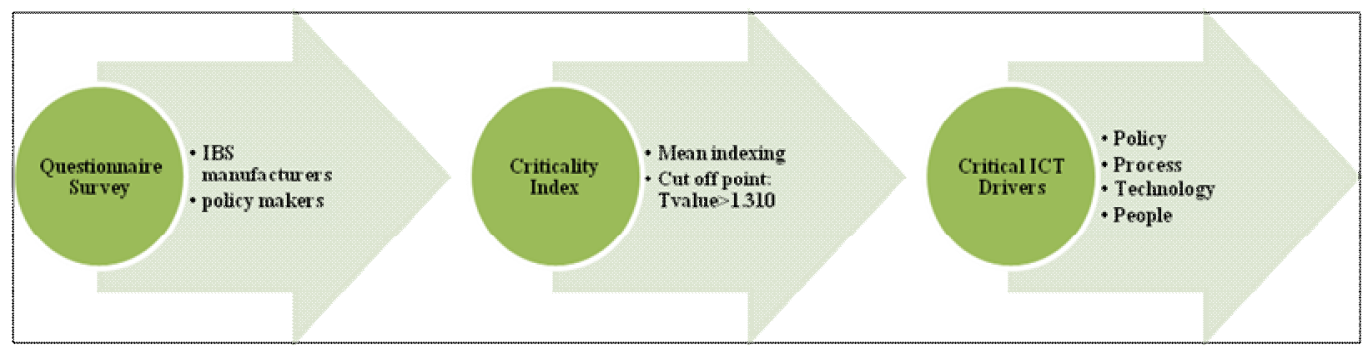

Figure 2. Flowchart of research methodology.

Referring to Figure 2, the IBS manufacturers and government policy makers were asked to rate the drivers for increased ICT uptake in IBS process management from Insignificant to Very Significant range. In order to identify the critical rating from all the sub-components of the ICT-barriers, the mean is fixed at scale ' 3.5 ' since ratings above ' 3 ' represent 'moderate significant', '4' represent 'significant' and ' 5 ' represent 'very significant'. The rankings for the ICT uptake drivers can be obtained by calculating the critical value of the variables. The critical $t$-value, $t(30,0.10)=1.310$ with confidence interval $90 \%(\alpha=0.10)$ was set in this study. T-test analysis was employed to rule out the ICT driver components which carry the mean value lesser than 3.5. ICT uptake drivers with t-values that are greater than the critical t-value of 1.310 will be shortlisted as the critical drivers to ICT 
uptake. Similar studies which applied mean indexing and t-tests are [25] which rated the criticality index for the importance of the sustainability-related cost components and [26] using mean indexing to discuss the importance of evaluation elements for customer satisfaction in project management. Apart from that, t-test analysis has been used in past research in identifying the relative important indicators [27, 28]. The critical drivers to ICT uptake are identified from the four driver elements (as shown in Figure 1).

\section{Data Analysis}

Critical drivers function as key enablers to specifically catalyse the proposed solutions to improve ICT uptake amongst the stakeholders. Hence, Table 2 summarises the top ten critical drivers to ICT uptake with t-values greater than 1.310. Ten of these critical ICT uptake drivers are under the ICT uptake elements of People, Technology and Policy, where Process is no longer within the top ten drivers.

Table 2. Critical drivers to ICT uptake.

\begin{tabular}{cllc}
\hline Rank & $\begin{array}{c}\text { Driver } \\
\text { Elements }\end{array}$ & \multicolumn{1}{c}{ Drivers } & $\begin{array}{c}\text { T-Value } \\
\text { (cut off point }>\mathbf{1 . 3 1 0})\end{array}$ \\
\hline 1 & People & Top management support and commitment & 8.469 \\
\hline 2 & Technology & Improve availability of the technologies & 8.088 \\
\hline 3 & Policy & $\begin{array}{l}\text { More cooperation between government and IBS } \\
\text { players to promote and implement ICT }\end{array}$ & 7.478 \\
\hline 4 & People & Devise better training procedures & 7.045 \\
\hline 5 & Technology & Provide adequate ICT support (in-house or external) & 6.225 \\
\hline 6 & Policy & Refine IBS Roadmap to encourage greater ICT uptake & 5.903 \\
\hline 7 & Technology & $\begin{array}{l}\text { Allocate adequate resources to implement and upgrade } \\
\text { ICT tools }\end{array}$ & 5.491 \\
\hline 8 & Technology & $\begin{array}{l}\text { Consistent commitment and support to use BIM as a } \\
\text { primary process and technology }\end{array}$ & 5.479 \\
\hline 9 & Policy & More ICT course syllabus to start from tertiary level & 4.507 \\
\hline 10 & Policy & Revision of reward systems & 4.452 \\
\hline
\end{tabular}

There are two critical drivers under the People element, namely top management support and commitment and devise better training procedures. [29] refers People to adequate skills, understanding of and belief in the technology. Thus, top down commitment is crucial in every organization, so to ensure all decision making are able to be passed down. Strong commitment from top management, including the senior leadership of an organization, is critical to ensuring technological acceptance by creating a supportive context for IT within the organization [30, 31].

The second most critical ICT uptake driver element is Technology. In the latest study technology plays a moderating role on the relationship between government and a construction organisation readiness level in implementing e-procurement [32]. In order to increase the adoption of ICT in IBS management process, there is a need to first improve the availability of technologies. Studies showed that appropriate training increases the likelihood that IT will be accepted, since training tends to bring about better understanding and more favorable attitudes toward the technology and to result in more frequent use of it $[33,34]$. Adequate resources are to be rightfully allocated to implement and upgrade ICT tools whilst consistent commitment to support the use of BIM in the IBS processes. Commitment focuses on end-users who devote themselves to using ICT whereas organisational commitment focuses on top managers who support end-users to use IT/ICT [35]. An organisation's top management also needs to be committed to support and allocate adequate resources for technology investment such as ICT. Commitment is essential to avoid IT project failure [36, 37].

Lastly, Policy is also found to be a critical driver element to greater ICT uptake improvement. The role of government has a stronger influence on a construction organisation readiness level in implementing ICT [38]. IBS Manufacturers and the Government policy makers agreed that more 
cooperation is needed between the government and IBS players in order to promote and implement ICT. Other than that, the IBS Roadmap has to be refined and more ICT course syllabus to touch the grass root education. One recurring ICT driver mentioned throughout this study is to revise the reward system [38].

\section{Conclusion and the Way Forward}

The result from the criticality index provide the rankings for the ten most critical ICT uptake drivers. It is a comprehensive and detailed account of different critical drivers to ICT uptake, enabling decision makers and organisational strategists a platform to work on further development required in adopting ICT. Further research can be executed to incorporate strategies to eliminate barriers to ICT uptake.

\section{Acknowledgement}

This work was supported by RAGS Universiti Tun Hussein Onn Malaysia (UTHM).

\section{References}

[1] IBS Roadmap 2003-2010, Construction Industry Development Board, Kuala Lumpur, (2003).

[2] A. Gibb and Pendlebury, Buildoffsite: Glossary of Term Buildoffsite UK, London, (2005).

[3] T. Venables and R. Courtney, Modern methods of construction in Germany - playing the off-site rule, Rep. of a Department of Trade and Industry (DTI) Global Watch Mission, London, (2004).

[4] W. Pan, A.G.F. Gibb and A.R.J Dainty, Perspectives of housebuilders on the use of offsite modern methods of construction, Constr. Manage. Econ., 25(2), 183-194, (2007).

[5] V.W.Y. Tam, C.M. Tam, S.X. Zeng and W.C.Y Ng, Towards adoption of prefabrication in construction, Building and Environment, 42, 3642-3654, (2007).

[6] C.M. Eastman and R. Sacks, Relative productivity in the AEC industries in the United States for on-site and off-site activities, Journal of Construction Engineering and Management, July, 517526, (2008).

[7] J. Lessing, A. Ekholm and L. Stehn, Industrialized housing - definition and categorization of the concept, The 13th International Group for Lean Construction, Sydney (2005).

[8] Z. Hamid, K.A.M. Kamar, M. Zain, K. Ghani and K. Rahim, Industrialized building system (IBS) in Malaysia: The current state and R\&D initiatives, Malaysia Construction Research Journal, 2(1), 1-13, (2008).

[9] K.A.M. Kamar, Industrialised Building System (IBS): Chronology of Adoption in Malaysia, International Islamic University Malaysia Press, (2011).

[10]CREAM, The 7th Industrialised Building System (IBS) Roundtable Workshop. Technology Foresight Report, Construction Research Institute of Malaysia, 1-27, (2011).

[11]K.A.M. Kamar and Z.IHamid, Modernising the Malaysian construction industry through the adoption of industrialised building system (IBS), The Sixth International Conference on MultiNational Joint Ventures for Construction Works, Kyoto, 1-14, (2010).

[12]P.S.E. Ang. Barrier-driver model for enhancement of ICT implementation in IBS production management process in construction industry, PhD Thesis, Universiti Tun Hussein Onn Malaysia, Johor, (2015).

[13]M. Alshawi, Future IT challenges in project management. In project management and IT, The 7th Annual Conference of the Project Management Institute: Gulf Branch, Bahrain, 1-19 (2000).

[14]L. Faraj and M. Alshawi. SPACE: Simultaneous prototyping for an integrated construction environment, INCITE, 466-484, (2000).

[15]J. Underwood and M. Alshawi, Data and process models for the integration of estimating and valuation, Computer-Aided Civil and Infrastructure Engineering, 12(5), 369-381, (1997). 
[16]M.A. Hunt, Strategic implementation of information technology within the construction industry, Doctoral Dissertation, University of Salford, (1995).

[17]S. Basu and P. Deshpande, Wipro's people processes: A framework for excellence, (2004). <available from http://www.wipro.com/insights/wipropeopleprocesses.htm>

[18]C. Goolsby, Integrated people processes tools = Best-of-breed service delivery, (2001). < available from http: //itpapers.news.com/>

[19]F. Xerox, Aligning people processes and technology, (2003). <available from http: //www.fujixerox.com.au>

[20]B. Larkin, Aligning people process and technology, (2003). <available from http: //www.paperlesspay.org/articles/Technology.pdf>

[21]B. Emmett, IT service management: People process technology = business value, The IT Journal, Third Quarter, (2002). <available from http://www.hp.com/execcomm/itjournal/third_qtr_02/ article2a.html>

[22]Clemson, Definition of Policy, Clemson University, (2007). <available from http //www.clemson.edu/research/orcSite/orcIRB_DefsP.htm.>

[23]A.R. Md Nor, Statistical Methods in Reserch, Pearson, Malaysia, (2009).

[24]R. Fellows and A. Liu, Research Methods for Construction, Wiley-Blackwell, West Sussex, (2008).

[25]K.C. Goh and J. Yang, Importance of sustainability-related cost components in highway infrastructure: perspective of stakeholders in Australia, Journal of Infrastructure Systems, 20(1), (2013).

[26]J.B. Yang and S.C. Peng, Development of a customer satisfaction evaluation model for construction project management, Building and Environment, 43(4), 458-468, (2008).

[27]J. Wong and H. Li, Development of a conceptual model for the selection of intelligent building systems, Building and Environment, 41(8), 1106-1123, (2006).

[28]Z. Shehu and A. Akintoye, Major challenges to the successful implementation and practice of programme management in the construction environment: A critical analysis, International Journal of Project Management, 28(1), 26-39, (2010).

[29]K. Ruikar, C.J. Anumba and P.M. Carrillo. Verdict-An e-readiness assessment application for construction companies, Automation in construction, 15(1), 98-110, (2006).

[30]P. Weill, The relationship between investment in information technology and firm performance: a study of the valve manufacturing sector, Information Systems Research, 3(4), 307-333, (1992).

[31]D.S. Bajwa, A. Rai and I. Brennan, Key antecedents of executive information system success: A path analytic approach, Decision Support Systems, 22(1), 31-43, (1998).

[32]Q. Tran, D. Huang, B. Liu and H.M. Ekram, A construction enterprise's readiness level in implementing eprocurement: a system engineering assessment model, Systems Engineering Procedia, 131-141, (2011).

[33]L. Raymond, The impact of computer training on the attitudes and usage behavior of small business managers, Journal of Small Business Management, 26(3), (1988).

[34] V. Venkatesh, Determinants of perceived ease of use: Integrating control, intrinsic motivation, and emotion into the technology acceptance model, Information Systems Research, 11(4), 342$365,(2000)$.

[35]V. Peansupap, An exploratory approach to the diffucion of ICT in a project environment, Phd Thesis, (2004).

[36]D. Leonard-Barton and J.J. Sviokla, Putting expert systems to work, Harvard Business Review, 91-98, (1988).

[37]R.L. Thompson, C.A. Higgins and J.M. Howell, Personal computing: Toward a conceptual model of utilization, MIS Quarterly, 15(1), 125-143, (1991).

[38]R. Mahbub, Readiness of a developing nation in implementing automation and robotics technologies in construction: A case study of Malaysia, The 6th International Conference on Construction in the 21st Century, Kuala Lumpur, (2011). 